\title{
Commentary: We should not forget the aortic valve allograft
}

\author{
Francisco Diniz Affonso da Costa, MD
}

Short- and long-term outcomes of surgical treatment of patients with active aortic valve bacterial endocarditis are influenced by multiple factors, including microbiology, patient-related factors, optimal perioperative care, timing of intervention, meticulous surgical techniques, and eventually by the type of the replacement device. ${ }^{1}$

Previous studies have suggested that aortic valve allografts were associated with lower rates of early and late reinfections, and, as a consequence, became the valve of choice for treating active aortic valve infections in many centers. ${ }^{2}$ More recently, however, this concept has been challenged, and several reports failed to demonstrate that prosthesis type has significant impact on patient survival and reinfection rates. ${ }^{3-5}$

In this issue of the Journal, Witten and colleagues ${ }^{6}$ provide us with an extended and detailed analysis on the continuing risks of aortic allograft infection in a large cohort of patients with and without endocarditis and with long-term follow-up extending up to 20 years. The authors conclude that the overall infection risks after aortic valve root replacement are uncommon and possibly lower than conventional replacement devices. However, looking from a different perspective, the data also suggest that, even for allografts, this complication is not negligible, as they demonstrated by the conditional probabilities analysis, which focuses on the risks of intrinsic allograft infection if competing risks are eliminated. The hazards were even greater in patients with endocarditis, emphasizing the importance of patient-related factors.

\footnotetext{
From the Department of Cardiovascular Surgery, Instituto de Neurologia e Cardiologia de Curitiba - INC Cardio, Curitiba, Paraná, Brazil.

Disclosures: Francisco Diniz Affonso da Costa has a patent in decellularization technique.

The Journal policy requires editors and reviewers to disclose conflicts of interest and to decline handling or reviewing manuscripts for which they may have a conflict of interest. The editors and reviewers of this article have no conflicts of interest.

Received for publication May 8, 2021; revisions received May 8, 2021; accepted for publication May 10, 2021; available ahead of print May 14, 2021.

Address for reprints: Francisco Diniz Affonso da Costa, MD, Instituto de Neurologia e Cardiologia de Curitiba - INC-Cardio, Rua Henrique Coelho Neto, 55, 82200-

120 Curitiba, Paraná, Brazil (E-mail: fcosta13@mac.com).

J Thorac Cardiovasc Surg 2023;165:1316-7

$0022-5223 / \$ 36.00$

Copyright (c) 2021 by The American Association for Thoracic Surgery

https://doi.org/10.1016/j.jtcvs.2021.05.022
}

There are no randomized studies comparing allografts with stented prosthesis in patients with active bacterial endocarditis, and the few available observational studies are limited to a relatively small number of patients with only short- to mid-term follow-up. ${ }^{4,5}$ In most of these studies, however, it becomes apparent that patients with complex destructive root anatomies, prosthetic valve endocarditis, and infections caused by resistant fungi or bacteria tended to be more often treated with an allograft root replacement. ${ }^{1}$ Unfortunately, the study by Witten and colleagues, ${ }^{6}$ by not including a control group of patients operated with conventional prosthetic valves, does not allow us to make any inference regarding the alleged allograft superior resistance to infection. In that sense, the institutional philosophy to treat noninvasive cases with conventional stented prosthesis and reserve allografts mainly for cases with more advanced root destruction may be considered somewhat empirical and intuitive but still lacks rigorous scientific confirmation and supportive data.

In contrast, we certainly agree with the authors that, from the technical aspect, the soft and pliable tissues of the allograft facilitate a perfect anatomical reconstruction of the aortic root, minimize the need of using external foreign material support such as Teflon felts or pericardial strips, and provide better hemodynamic characteristics and laminar flow when compared with other replacement devices, all 


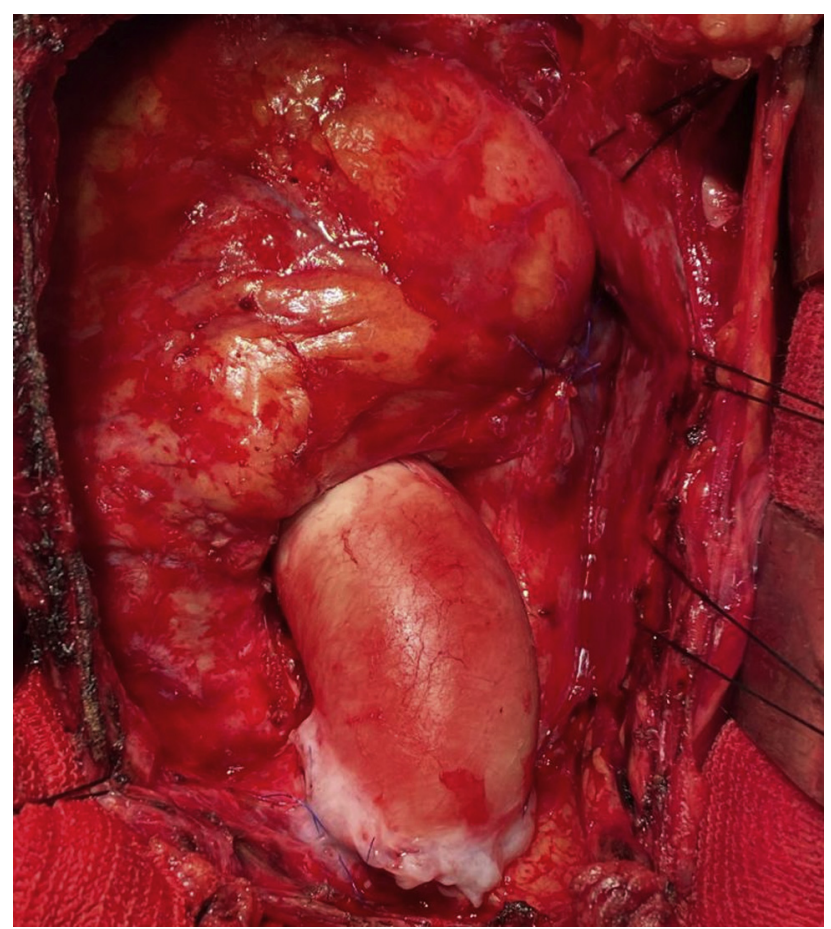

FIGURE 1. Aortic valve allograft replacing the aortic valve, root, and ascending aorta.

of which are strong arguments in favor of the aortic root allograft replacement. ${ }^{1}$ We also concur with the authors that the aortic valve allograft should not be abandoned and, when performed in experienced centers, is a valuable alternative not only in patients with endocarditis but also in cases with small aortic roots, complex redo scenarios, and in some younger patients who may not be candidates for a Ross operation and have contraindications or are not willing to be in permanent anticoagulation (Figure 1). ${ }^{1,3}$

The ability to perform aortic root replacement with similar results compared with conventional aortic valve replacement coupled with newer tissue-processing technologies such as decellularization that may improve long-term allograft durability may renew the interest for broader indications of the aortic allograft. ${ }^{7,8}$ However, this will need to be supported by strong scientific data, such as those provided by Witten and colleagues.

\section{References}

1. Nappi F, Avtaar Singh SS, Timofeeva I. Learning from controversy: contemporary surgical management of aortic valve endocarditis. Clin Med Insights Cardiol. 2020;14:1179546820960729.

2. Haydock D, Barratt-Boyes B, Macedo T, Kirklin JW, Blackstone E. Aortic valve replacement for active infectious endocarditis in 108 patients. A comparison of freehand allograft valves with mechanical prostheses and bioprostheses. J Thorac Cardiovasc Surg. 1992;103:130-9.

3. Glaser N, Jackson V, Holzmann MJ, Franco-Cereceda A, Sartipy U. Prosthetic valve endocarditis after surgical aortic valve replacement. Circulation. 2017; 136:329-31.

4. Kim JB, Ejiofor JI, Yammine M, Camuso JM, Walsh CW, Ando M, et al. Are homografts superior to conventional prosthetic valves in the setting of infective endocarditis involving the aortic valve? J Thorac Cardiovasc Surg. 2016;151: 1239-46. 48.e1-2.

5. Yanagawa B, Mazine A, Tam DY, Juni P, Bhatt DL, Spindel S, et al. Homograft versus conventional prosthesis for surgical management of aortic valve infective endocarditis: a systematic review and meta-analysis. Innovations (Phila). 2018; $13: 163-70$.

6. Witten JC, Houghtaling PL, Shrestha NK, Gordon SM, Jaber W, Blackstone EH, et al; on behalf of the Infectious Endocarditis Working Group. Aortic allograft infection risk. J Thorac Cardiovasc Surg. 2023;165:1316-7.e9.

7. da Costa FD, Costa AC, Prestes R, Domanski AC, Balbi EM, Ferreira AD, et al. The early and midterm function of decellularized aortic valve allografts. Ann Thorac Surg. 2010;90:1854-60.

8. Horke A, Bobylev D, Avsar M, Meyns B, Rega F, Hazekamp M, et al. Paediatric aortic valve replacement using decellularized allografts. Eur J Cardiothorac Surg. 2020;58:817-24. 